\title{
A Newly Recorded Sea Urchin (Echinoidea: Spatangoida: Spatangidae) from Geomundo Island, Korea
}

\author{
Sook Shin* \\ Department of Life Science, Sahmyook University, Seoul 139-742, Korea
}

\begin{abstract}
A sea urchin was collected from Geomundo Island of Jeollanam-do, Korea on July 3, 2009. This specimen was classified as Spatangus luetkeni A. Agassiz 1872 belonging to the family Spatangidae of order Spatangoida based on the morphological characteristics. This genus and species are newly recorded in Korea. It is distinct morphological characters that test is thick and strong, six to eight primary tubercles are in 1 and 4 interambulacra, sternum is equipped with little keel, and color in alcohol is dark violet. This species inhabits tropical waters and usually distributes over the West Pacific from southern Japan to New Zealand.
\end{abstract}

Keywords: Spatangus luetkeni, sea urchin, morphology, Geomundo Island, Korea

\section{INTRODUCTION}

Sea urchins which are obviously bilaterally symmetrical, have an anterior mouth and are informally termed "heart urchins" are organized into the order Spatangoida representing one of the most easily recognizable groups within the class Echinoidea (Smith, 2004). This order is the most diverse one of all the extant orders of sea urchin (Stockley et al., 2005). They are found in all the major oceans of the world, and vary in their geographical distribution from highly localized to highly cosmopolitan. Family Spatangidae of order Spatangoida comprises 15 species within two genera in the world (Kroh and Mooi, 2013). In this study the genus Spatangus and $S$. luetkeni are newly reported in Korea, and the key to the families of suborder Brissidina is prepared. To date, six species of order Spatangoida including this species have been recorded in Korea (Shin and Rho, 1996; Shin, 2012).

The specimen was collected from Geomundo Island on July 3, 2009 and was preserved in 95\% ethyl alcohol. The important morphological characters were photographed by a digital camera (Nikon D7000; Nikon Co., Tokyo, Japan), light- and stereo-microscopes (Nikon Eclipse 80 $i$; Nikon SMZ1000). Identification of this specimen was referred to HL Clark (1917), Mortensen (1951) and Shin (2012). Specimen was deposited in the Marine Echinoderm Resource
Bank of Korea (MERBK), Sahmyook University, Seoul, Korea.

\section{SYSTEMATIC ACCOUNTS}

Class Echinoidea Leske, 1778

Subclass Euechinoidea Bronn, 1860

Order Spatangoida L. Agassiz, 1840

Suborder Brissidina Stockley, Smith, Littlewood, Lessios \& MacKenzie-Dodds, 2005

Key to the families of suborder Brissidina in Korea 1. Internal fasciole present ….................. Loveniidae

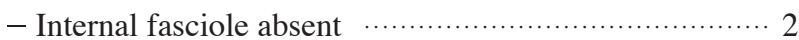

2. Peripetalous fasciole present …................ Brissidae

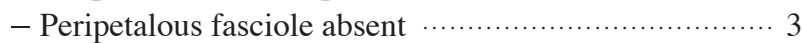

3. Sternal system completely covered with tubercles Spatangidae

- Sternal system not completely covered with tubercles

Maretiidae

Family Spatangidae Gray, 1825

Test heart shaped, oval outline. Apical system ethmolytic. Subanal fasciole present, but no other fascioles. Petals well (c) This is an Open Access article distributed under the terms of the Creative Commons Attribution Non-Commercial License (http://creativecommons.org/ licenses/by-nc/3.0/) which permits unrestricted non-commercial use, distribution, and reproduction in any medium, provided the original work is properly cited.

pISSN 2234-6953 eISSN 2234-8190
*To whom correspondence should be addressed

Tel: 82-2-3399-1717, Fax: 82-2-3399-1729

E-mail: shins@syu.ac.kr 
developed. Ventral part of poriferous zones usually rudimentary.

Type genus: Spatangus Gray, 1825.

Genera 3 (1 in Korea).

1*Genus Spatangus Gray, 1825

Spatagus OF Müller, 1776: 236.

Spatangus Gray, 1825: 527; L Agassiz and Desor, 1847: 6; HL Clark, 1917: 233; 1925: 224; Mortensen, 1951: 7; Nisiyama, 1968: 199; Rowe and Gates, 1995: 244; Kroh and Mooi, 2013: 123430.

Prospatangus Lambert, 1902: 55; 1915: 192; Lambert and Thiery, 1924: 459.

Test rigid, broad oval outline, with a fairly deep frontal ambulacral groove. Paired ambulacra form very distinct petals, nearly closed distally, not sunken. Apical system subcentral, with four genital pores, ethmolytic. Labrum prominent. Sternum generally narrow. Periproct on truncated posterior end.

Type species: Spatangus purpureus O.F. Müller, 1776. Species 14 (1 in Korea).

2*Spatangus luetkeni A. Agassiz, 1872 (Fig. 1)

Spatangus luetkeni A Agassiz, 1872: 57; 1873: 564; HL Clark, 1917: 238, Pl. 146, fig. 17, pl. 157, figs. 5, 6; Mortensen, 1951: 18; Rowe and Gates, 1995: 245; Kroh and Mooi, 2013: 513548.

Material examined. 1 specimen by Hyun Sik Lim, Geomundo Island, 3 July 2009.

Description. Test medium-sized, thick, strong, oval outline, regularly indented anterior, with a fairly deep broad frontal ambulacral groove, with dorsal side regularly arched both transversely and longitudinally, ventral side flat, truncated at posterior end. Apical system with four genital pores, subcentral, lying anterior, vertex slightly posterior. Madreporite extending beyond posterior ocular plates. Lateral petals moderately broad petaloid, comparatively short, occupying less than two thirds of length to test margin. Peristome lying anterior, usually distinctly sunken, with fairly conspicuous phyllodes, labrum prominent, generally tuberculated. Sternum generally narrow, with irregularly arranged large primary tubercles carrying slightly bent large spines with broadly rounded spoon-like ends. Small tubercles covering ventral surface including anterior groove, uniform size, carrying minute slender curved spines. Apical portion of 1 and 4 lateral interambulacra bearing six to eight irregularly arranged primary tubercles carrying large spines. On outer slopes of anterior groove, adjoining ambulacral zones, irregular vertical lines of large primary tubercles carrying large spines present. Periproct on truncated posterior end large, broad ovoid. Dorsal plastron elongated. Subanal plastron heart-shaped, about one and a half times as broad as long and not exceeding in width of widest part of dorsal plastron. Subanal fasciole present, but no other fascioles. Only tridentate pedicellariae abundant, triphyllous pedicellariae a few, without globiferous and ophiocephalous pedicellariae.

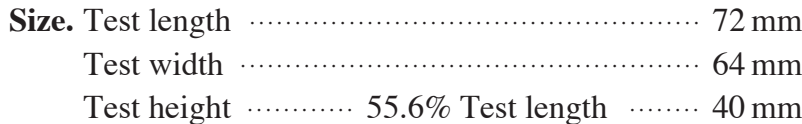

Color. Test is dark violet and spines are olive in alcohol.

Distribution. Korea (Geomundo Island), Japan, China, Taiwan, New Zealand, Australia (Tasmania).

Remarks. This species is peculiar by clearly showing the arrangement of skeletal plates on the dorsal side and the distributed pattern of large spines and by having abundant tridentate and a few triphyllous pedicellariae, but no globiferous and ophiocephalous pedicellariae which were mentioned by Agassiz (1872), HL Clark (1917), and Mortensen (1951). It is distinct morphological characters that test is thick and strong, six to eight primary tubercles are in 1 and 4 interambulacra, sternum is equipped with little keel, and color in alcohol is dark violet. Two different forms of tridentate pedicellariae having short and broad or long and slender stalks were observed in this specimen.

\section{ACKNOWLEDGMENTS}

This study was supported by the Project of the Survey of Korean Indigenous Species, NIBR, and a grant from Marine Biotechnology Program Funded by Ministry of Oceans and Fisheries, Korea.

\section{REFERENCES}

Agassiz A, 1872. Revision of the Echini. Memoirs of the Comparative Zoölogy at Harvard College, Cambridge, 7:1-378.

Agassiz A, 1873. Revision of the Echini. Memoirs of the Comparative Zoölogy at Harvard College, Cambridge, 7:379-628.

Clark HL, 1917. Hawaiian and other Pacific echini. No. 2. The Echinodeidae, Nucleolitidae, Urechinidae, Echinocorythidae, Calymnidae, Pourtalesiidae, Palaeostomatidae, Aeropsidae, Palaeopneustidae, Hemiasteridae, and Spatangidae. Memoirs of the Museum of Comparative Zöology at Harvard College, Cambridge, 46:81-783.

Korean name: ${ }^{1 *}$ 염통성게속(신칭), ${ }^{2 *}$ 뤼트켄염통성게 (신칭) 
A
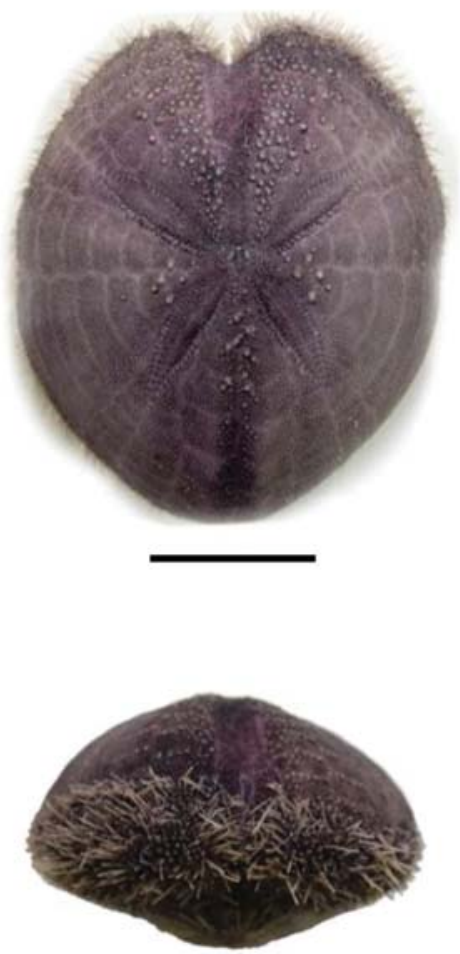

D

G

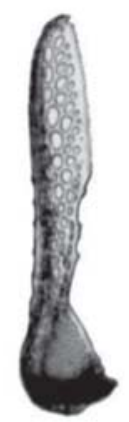

B

E

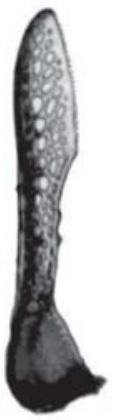

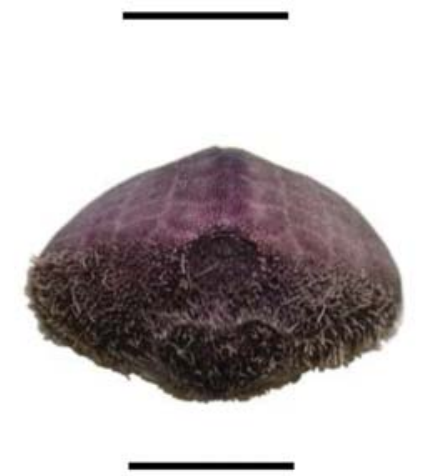

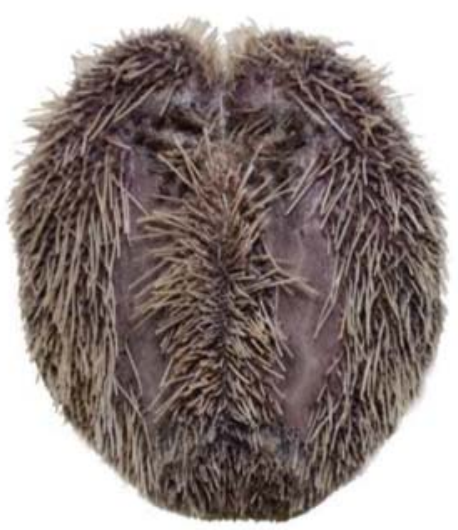

H

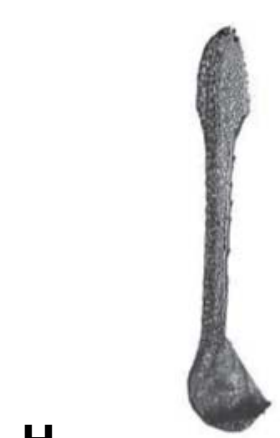

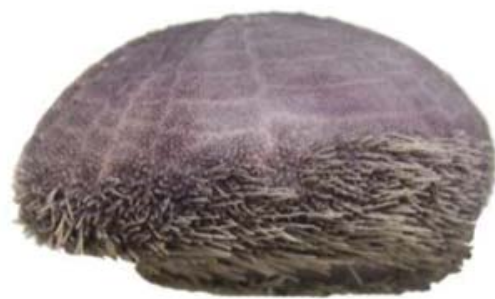

C
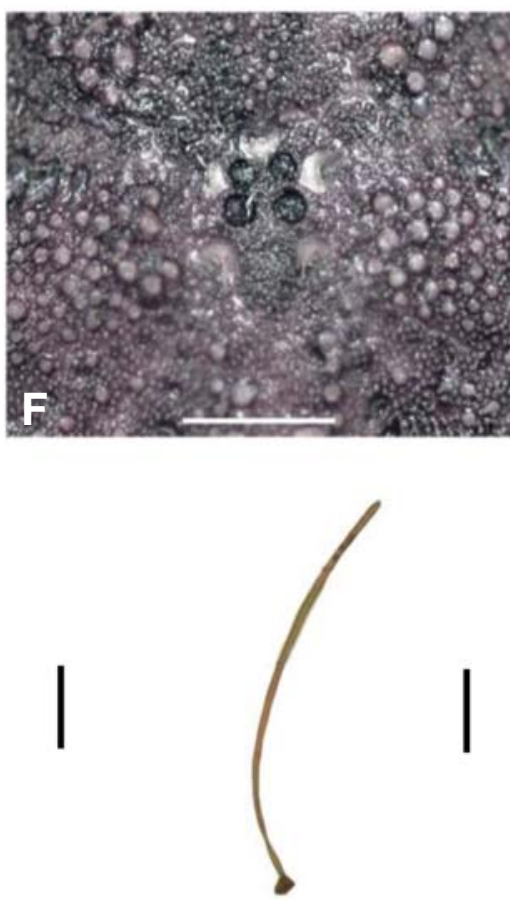

\section{I}
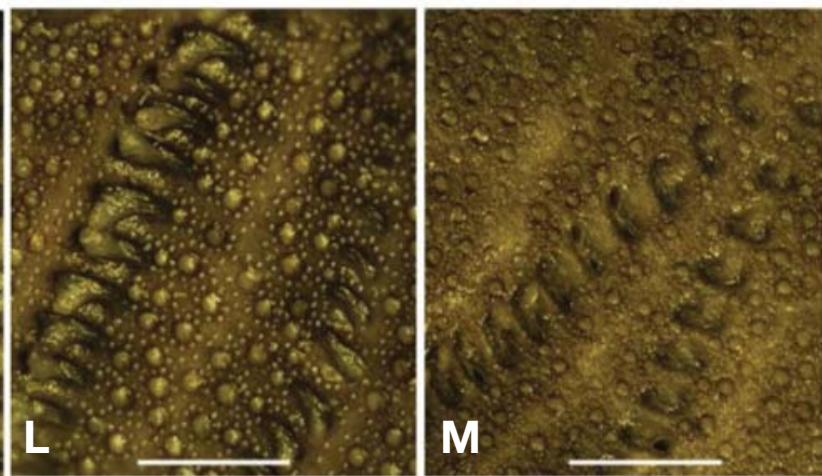

Fig. 1. Spatangus luetkeni. A, Dorsal side; B, Ventral side; C, Lateral side; D, Anterior view; E, Posterior view; F, Apical system; G, $\mathrm{H}$, Valves of tridentate pedicellaria; I, Supporing rod of penicillate podia of phyllode; J, Basal parts of large spines; $\mathrm{K}$, Large spines; L, Branchial podia of petaloid; M, Petaloid removed branchial podia. Scale bars: $A-E=3 \mathrm{~cm}, F, J-M=5 \mathrm{~mm}, \mathrm{G}, \mathrm{H}=250 \mu \mathrm{m}, \mathrm{I}=30 \mu \mathrm{m}$. 
Kroh A, Mooi R, 2013. World Echinoidea database [Internet]. The world register of marine species (WoRMS), Accessed 18 Jan 2013, <http://www.marinespecies.org/echinoidea>.

Mortensen T, 1951. A Monograph of the Echinoidea. V, 2. Spatangoida II. Amphisternata II. Spatangidae, Loveniidae, Pericosmidae, Schizasteridae, Brissidae. C.A. Reitzel, Copenhagen, pp. 1-593.

Rowe FWE, Gates J, 1995. Echinodermata. In: Zoological catalogue of Australia. Vol. 33 (Ed., Wells A). CSIRO Australia, Melbourne, pp. 1-510.

Shin S, 2012. Invertebrate fauna of Korea. Vol. 32. Sea urchins: Echinodermata: Echinozoa: Echinoidea. National Institute of Biological Resources, Incheon, pp. 1-122.

Shin S, Rho BJ, 1996. Illustrated encyclopedia of fauna and flora of Korea. Vol. 36. Echinodermata. Ministry of Education, Seoul, pp. 1-780.

Smith AB, 2004. Phylogeny and systematics of holasteroid echinoids and their migration into the deep-sea. Palaeontology, 47:123-150.

Stockley B, Smith AB, Littlewood T, Lessios HA, MackenzieDodds JA, 2005. Phylogenetic relationships of spatangoid sea urchins (Echinoidea): taxon sampling density and congruence between morphological and molecular estimates. Zoologica Scripta, 34:447-468.

Received June 3, 2013 Revised September 5, 2013 Accepted September 10, 2013 